\title{
Regulation of Immune Responses and Chronic Inflammation by Fibroblast-Like Synoviocytes
}

\author{
Hiroyuki Yoshitomi* \\ Department of Regeneration Science and Engineering, Institute for Frontier Life and Medical Sciences, Kyoto University, \\ Kyoto, Japan
}

Synovial tissue is a membranous non-immune organ lining joint cavities where it supports local immune responses, and functions directly and indirectly in joint destruction due to chronic inflammatory diseases such as rheumatoid arthritis (RA). Fibroblast-like synoviocytes (FLS), the dominant non-immune cells of synovial tissues, mainly contribute to joint destruction via multiple mechanisms. In RA, FLS respond to endogenous ligands of pattern recognition receptors (PRRs) and inflammatory cytokines as non-immune cells. In addition, FLS aid in the activation of immune responses by interacting with immune

OPEN ACCESS

Edited by:

Teruki Dainichi,

Kyoto University, Japan

Reviewed by:

Toshihiro Nanki,

Toho University, Japan Sin-Hyeog Im

Pohang University of Science and Technology, South Korea

*Correspondence:

Hiroyuki Yoshitomi

yositomi@kuhp.kyoto-u.ac.jp

Specialty section:

This article was submitted to Immunological Tolerance and

Regulation,

a section of the journal

Frontiers in Immunology

Received: 07 January 2019

Accepted: 03 June 2019

Published: 19 June 2019

Citation:

Yoshitomi H (2019) Regulation of Immune Responses and Chronic Inflammation by Fibroblast-Like Synoviocytes.

Front. Immunol. 10:1395 doi: 10.3389/fimmu.2019.01395 cells and by supporting ectopic lymphoid-like structure (ELS) formation in synovial tissues. Moreover, FLS directly cause the pathogenicity of RA i.e., joint deformities. Here, we describe new findings and review the mechanisms underlying the regulation of immune reactions by non-immune FLS and their roles in inflammatory diseases such as RA.

Keywords: fibroblast-like synoviocytes (FLSs), synovial tissue, rheumatoid arthritis, non-immune cells, immune cells, autoantibodies, ectopic lymphoid-like structures (ELSs)

\section{INTRODUCTION}

Non-immune cells of target organs play essential roles in the pathogenesis of chronic inflammatory and autoimmune diseases, forming the basis of the unique features of each disease (1). Fibroblast-like synoviocytes (FLS) are non-immune cells found in synovial tissues. FLS function in the pathogenesis of rheumatoid arthritis (RA), a type of chronic systemic arthritis. Autoantibodies, such as rheumatoid factor (RF), and anti-citrullinated peptide antibodies (ACPAs) are unique features of RA, and their presence indicates strong involvement of $\mathrm{CD}^{+} \mathrm{T}$ cells and $\mathrm{B}$ cells in the RA pathogenesis (2). Therefore, cellular communication between FLS and hematopoietic immune cells may play a large role in the RA pathogenesis, including local autoantibody production in the RA synovium.

The synovium is a membranous organ lining the joint cavity. In normal physiological conditions within the joint cavity, the synovium supplies nutrients and the extracellular matrix (ECM) components of cartilage (3). FLS also strongly participate in the pathogenesis of RA. FLS support the development of the hyperplastic RA synovium as tertiary lymphoid organs (TLOs) by interacting with immune cells and organizing ectopic (tertiary) lymphoid-like structures (ELSs). Furthermore, FLS directly exert RA effector functions, which lead to joint deformity through osteoclastogenesis and the production of extracellular protease enzymes.

In this review, we describe new findings and examine the role of FLS in the RA pathogenesis. 


\section{FLS RESPONSES VIA PRRS}

Like stromal cells in other organs, such as the skin, gingiva, and lymph nodes (LNs), FLS play a role as innate immune cells by recognizing invading pathogens via PRRs such as Toll-like receptors (TLRs). Among the human TLR family, TLR1-7 is expressed by FLS (4). TLRs can recognize components of both pathogens and endogenous factors. Double-stranded and singlestranded RNA are recognized by TLR3 and TLR7, respectively. Necrotic cells in inflamed joints may be a source of endogenous ligands for these receptors (5). Endogenous ligands, such as heat-shock proteins and low-molecular-weight hyaluronan, were initially reported to be directly recognized by a heterodimer of TLR2/TLR4. However, highly pure ligands do not activate these receptors (6).

Of note, citrullination of endogenous ligands, such as fibrinogen and histones, stimulates the TLR4-mediated pathway $(7,8)$. Anti-TLR4 antibody significantly blocks the activation of monocytes by synovial fluid from RA patients exhibiting ACPAs (9), suggesting involvement of the TLR4-mediated pathway in the pathogenesis of RA. FLS are not activated by TLR9 plus CpG DNA (10). However, neutrophil extracellular traps (NETs) are internalized via the receptor for advanced glycosylation end products (RAGE)-TLR9 pathway, followed by promotion of the FLS inflammatory phenotype and human leukocyte antigen (HLA) class II upregulation (11). Thus, FLS recognize both pathogens and endogenous ligands through the PRRs, and these interactions lead to the pathogenesis of RA.

\section{FLS INTERACTIONS WITH IMMUNE CELLS}

Autoantibodies, such as RF and ACPAs, are an important feature of RA, and their presence provides evidence of the involvement of $\mathrm{CD} 4^{+}$helper T cells and $\mathrm{B}$ cells in the RA pathogenesis (2). The RA synovium frequently (40\%) exhibits ELSs, which are discrete clusters of T cells, B cells, and macrophages (12). Consistent with the activated immune responses of these ELSs (1), B cells clonally expand in the RA synovium, presumably due to autoantigens, rather than in peripheral blood (13). During these activated responses, communication between FLS-a type of stromal celland immune cells may lead to the signature RA phenotype. In this section, we review the interactions of FLS with each cell type.

\section{Interactions With Macrophages}

Under healthy conditions, resident monocytes are found in the intimal lining and sublining of synovial tissues $(3,14)$. Upon activation of synovial tissues, neoangiogenesis and chemokine recruitment function in the influx of peripheral monocytes into the synovium (3). In response to proinflammatory cytokines, FLS secrete chemoattractants, such as CCL2, CCL5, CCL8, CXCL5, and CXCL10, which leads to the recruitment of monocytes and macrophages (3). Cytokine networks at inflammatory sites contribute largely to the RA pathogenesis and the perpetuation of inflammation. Detailed analysis of the cytokine milieu of RA synovitis revealed that macrophages and fibroblasts are the major sources of proinflammatory cytokines (15). Anticytokine therapies, including anti-TNF and anti-IL-6, markedly improve the clinical results after RA treatment $(16,17)$. These cytokines form a vicious inflammatory cycle leading to synovial hyperplasia, influx of lymphocytes, and the production of effector proteins. Macrophages are the major source of IL- $1 \beta$ and TNF, and FLS in the intimal lining are the main source of IL-6 (15). Colony-stimulating factors, such as GM-CSF and M-CSF, are also produced primarily by FLS in the intimal lining (18). Upregulated GM-CSF production by IL-1 $\beta /$ TNF-stimulated FLS is involved in the local expansion of macrophages. GM-CSF rather than IFN- $\gamma$ plays an important role in the induction of HLA class II expression on macrophages in the RA synovium (Figure 1) (15). Indeed, anti-CXCL10 treatment and anti-GM-CSF receptor treatment are clinically effective for RA $(19,20)$.

Another aspect of the interaction between macrophages and FLS is the induction of osteoclasts, which are specialized bone-absorbing cells that differentiate from macrophages. Actively transformed RA synovium, the so-called pannus, destroys the cartilage matrix and can invade bone. At the tip of the pannus, multinuclear cell osteoclasts greatly absorb adjacent bone. RANKL has been identified as the factor responsible for the differentiation of osteoclasts from macrophages (21-23). Activated FLS produce large amounts of RANKL and another essential factor, M-CSF. Clinically, antiRANKL antibody significantly attenuates the bone destruction of RA (24).

\section{Interactions With T Cells}

$\mathrm{CD}^{+}$helper $\mathrm{T}$ cells are another important player in the RA pathogenesis. Genetic studies of RA-related genes revealed that T-cell-related genes, including HLA-DR, PTPN22, and CTLA4, are involved in RA (25), and that treatment that targets T cells is as effective as anti-TNF therapy (26). $\mathrm{CD} 4^{+} \mathrm{T}$ cells differentiate into several types of subsets depending on the differentiation environment. IL-17-producing helper T (Th17) cells, follicular helper $\mathrm{T}$ (Tfh) cells, and $\mathrm{PD}-1^{\text {hi }} \mathrm{CXCR} 5^{-}$peripheral helper $\mathrm{T}$ (Tph) cells are thought to be involved in RA (27-29). Th17 cells function in the activation of FLS, macrophages, endothelial cells, and chondrocytes mainly via the biological effects of IL-17A (30). However, clinical trials of neutralizing anti-IL-17 antibodies demonstrated that Th17 cells play a role in the pathogenesis of psoriatic arthritis but less in that of RA $(31,32)$. The strong involvement of autoantibodies, such as RF and ACPAs, in RA suggests that B-helper activity is a key function of $\mathrm{CD} 4^{+}$helper $T$ cells. In LNs or tonsils, Tfh cells exert B-helper activity, and aid in class switching and affinity maturation of antibodies via the activity of the master transcription factor BCL-6 (33). However, the BCL- 6 expression level is not increased in RA synovial CD4 ${ }^{+}$ $\mathrm{T}$ cells $(34,35)$ despite production of autoantibodies in the RA synovium (13). Recently identified by comprehensive analysis of clinical samples as a pathogenic $\mathrm{CD} 4^{+}$subset in RA patients (36), Tph cells also play a role in B-helper activity and ELS formation at inflammatory sites $(34,35,37)$.

Although not primary immune cells, FLS express immunerelated genes, including HLA Class II, the gene required for presenting antigens to $\mathrm{CD} 4^{+}$helper $\mathrm{T}$ cells, during the 

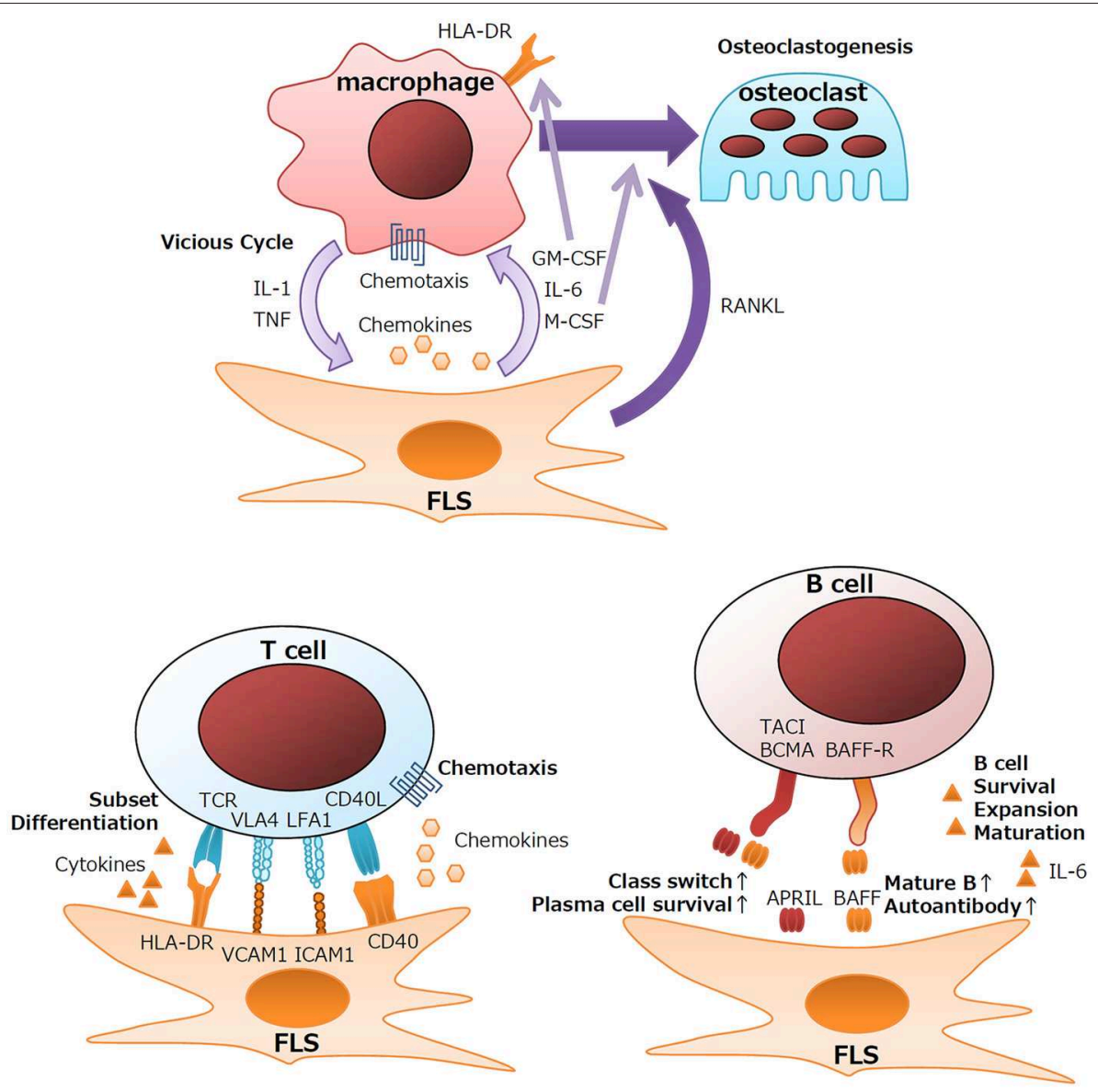

FIGURE 1 | Schematic outline of interactions between FLS and immune cells.

development of RA. FLS also function in the differentiation of T cells via cytokine production. TGF- $\beta$ is known to be involved in the differentiation of several types of T-cell subsets, such as inducible T reg (iTreg), Th17, and Tph cells (38), by inducing the transcription factors FoxP3 (39), RORC (40), and Sox4/Maf (37). Chemokines from FLS also help recruit T cells. CXCL9/10/11, CCL20, and CCL2 recruit Th1, Th17, and Tph cells via the cytokine receptors CXCR3, CCR6, and CCR2, respectively (36, 41-43). RA FLS also significantly express higher amounts of CX3CL1 (fractalkine), and the expression of its sole receptor, CX3CR1, is upregulated in $\mathrm{CD}^{+}{ }^{+}$and $\mathrm{CD} 8^{+} \mathrm{T}$ cells of patients with RA, suggesting the involvement of the CX3CL1/CX3CR1 axis in the pathogenesis of RA (44). Consistent with this, antiCX3CL1 treatment has significant clinical effects for RA (45). Membrane proteins and adhesion molecules also lead to the activation of $\mathrm{T}$ cells and FLS. CD40L produced by $\mathrm{CD} 4^{+} \mathrm{T}$ cells stimulates B-cell activity by stimulating CD40 signaling in B cells. Similarly, CD40L produced by T cells also stimulates FLS to release chemotactic molecules (46). LFA-3 on FLS and LFA-2 (CD2) on $\mathrm{T}$ cells are important for strengthening the adhesion between T cells and FLS (47). ICAM-1 and VCAM-1 expressed on FLS regulate the development of $\mathrm{T}$ cells by interacting with the integrins LFA-1 and VLA-4, respectively (48). Thus, FLS support the immunological functions of $\mathrm{T}$ cells via pleiotropic mechanisms (Figure 1).

\section{Interactions With B Cells}

The clinical relevance of autoantibodies in RA supports the important roles of $\mathrm{B}$ cells in the RA pathogenesis. Indeed, administration of the B-cell-depleting anti-CD20 antibody, rituximab, produces good clinical results for RA (49). Autoantibodies develop initially in the synovium rather than in peripheral blood and are class-switched during the development of RA (13), which indicates that the local synovial environment is a main contributor to the development and maturation of autoantibody-producing B cells.

Upon TLR3 stimulation, FLS produce large quantities of Bcell-activating factor (BAFF) and a proliferation-inducing ligand (APRIL) (50). Although both BAFF and APRIL bind to the receptor's $\mathrm{B}$-cell maturation antigen (BCMA), transmembrane activator, and cyclophilin ligand interactor (TACI), only BAFF can bind to the BAFF receptor (BAFF-R) (51). Therefore, BAFF and APRIL exert different biological effects on $B$ cells. BAFF is important for the maturation and survival of B cells; upregulated BAFF expression leads to an increase in the number of mature $B$ cells and autoantibody production in mice (52). In contrast, 
APRIL plays essential roles in class-switching of antibodies and the survival of plasma cells (51). However, the roles of BAFF and APRIL in RA remain to be determined. Anti-BAFF treatment for RA downregulates RF but has little effect on the clinical course of disease activity (53).

IL-6 is another key factor secreted by FLS that can affect B cell functions. In addition to its pleiotropic effects on multiple cell lineages, IL-6 plays key roles in the development of B cells. IL-6 is involved in the survival, expansion, and maturation of B cells (54), and it functions in the commitment to the Tfh cell subset via the induction of the transcription factor BCL-6 (55). Therefore, FLS support the function of B cells, including autoantibody production, and lead to the pathology of RA (Figure 1).

\section{FLS Support ELS Formation}

Frequent ELS formation is an important feature of the RA synovium (12). In ELS, generally upregulated immune responses lead to autoantibody production in rheumatic diseases, or to anti-viral immunity or anti-tumor immunity depending on the features of diseases (1, 56-58). FLS play essential roles in ELS formation and in the regulation of ELS immune responses. During the developmental process of secondary lymphoid organs, such as LNs and tonsils, interactions between lymphoid tissue inducer (LTi) cells and lymphoid tissue organizer (LTo) cells coordinate organ formation. Similarly, FLS express signature genes of LTo cells and their derivative fibroblastic reticular cells (FRC) such as LT $\beta$ R, IL-7, RANKL, CXCL13, CXCL12, CXCL21, CXCL19, VCAM-1, ICAM-1, and gp38 (12, $34,48,59-64)$. In addition, FLS also exert nurse-like activity by supporting lymphocyte pseudoemperipolesis (active migration of lymphocytes into the cytoplasm of nurse-like cells). FLS under RA or of non-RA conditions support the pseudoemperipolesis of T cells, B cells, and NK cells, aiding in their survival, activation, or functions such as IgG production $(60,65,66)$. Due to such activity of FLS, TLO cells are (i) induced via initiators, such as LT $\alpha \beta$, IL-7, and RANKL (67), (ii) expanded via propagators, such as CXCL13/12/21/19, and (iii) maintained via adhesion molecules and nurse-like activity (Figure 2).

\section{Involvement in Organ-Specific Immune Responses}

Although ELS exhibit an overlapping structure in several inflammatory diseases, the target autoantigens depend on the diseases. In the salivary gland ELSs of patients with Sjögren syndrome, B cells and plasma cells are frequently reactive against the ribonucleoproteins Ro/SSA and La/SSB, whereas autoantibodies specific for RA are RF and ACPA. These differences may be partly attributed to the differences in nonimmune cells of target organs. One notable feature of FLS is their contribution to the joint architecture via formation of synovial anatomical components: the intimal lining and sublining. Indeed, FLS grown in three-dimensional culture selfdirect their architecture to be very similar to that of the intimal lining (14), which borders between joint spaces and synovial tissues. This signature architecture of joints may function in the enrichment of disease-specific antigens, such as synovial fluid NETs, whose citrullinated histones are major targets of ACPA (12,
68, 69). Alternatively, a protein of FLS, citrullinated calreticulin of FLS, or citrullinated aggrecan from cartilage are other targets for RA autoreactive B cells or $\mathrm{T}$ cells, respectively $(70,71)$. These findings suggest a connection between autoantibodies and organ-specific antigens depending its structure and components.

\section{FLS EXERT EFFECTOR FUNCTIONS OF RA}

As a consequence of activated immune responses, hyperplastic synovial tissues of RA (pannus) aggressively invade adjacent cartilage, tendon, and bones, leading to the destruction of multiple joints. Clinical studies demonstrated that the vasculature of the RA synovium reflects joint inflammation and correlates with future joint deformities. In this joint destruction, FLS directly exert effector functions. In this section, we discuss FLS effector functions and their regulation.

\section{Synovial Hyperplasia}

As mentioned above, FLS are highly involved in the formation of the intimal lining of synovial tissues (14). The intimal lining comprises 1-3 cell layers in normal physiological conditions, but its thickness increases to 10-15 cell layers in the activated RA synovium $(3,46)$. Upregulated expression of effector factors in the hyperplastic intimal lining suggests the importance of the dysregulation of the intimal lining in the RA pathogenesis $(15,18)$. Dysregulation of apoptosis and proliferation of FLS via multiple genes may play a role in this hyperplasia (7274). In three-dimensional culture conditions, the combination of growth factors (e.g., PDGF and TGF- $\beta$ ) with inflammatory cytokines (e.g., TNF) strongly induces hyperplasia of the synovial lining via activation of the PI3K-Akt pathway $(75,76)$. Adhesion molecules, such as cadherins and integrins, play essential roles in the formation and maintenance of the synovial lining. A deficiency in cadherin 11 leads to the disappearance of the intimal lining in mice (77). Integrin $\alpha 9 \beta 1$ is also preferentially expressed by FLS. Neutralization of integrin $\alpha 9 \beta 1$ or knockdown of its ligand tenascin- $\mathrm{C}$ abrogates the formation of the synovial lining (78). Based on these findings, in addition to integrin $\alpha 9 \beta 1$ and cadherin 11, FLS may play a role in the formation of the synovial lining. These adhesion molecules also have effector functions in RA. RA FLS cultured in a three-dimensional manner secrete greater amounts of effector factors, such as MMP1, MMP3, IL-6, or RANKL, than monolayer FLS.

The protein gp38, a FRC signature gene, may also function in the regulation of TLO size. Regarding LNs, gp38 is involved in the FRC regulation of LN size. Interaction of gp38 with its ligand CLEC2, which is preferentially expressed by dendritic cells in LNs, reduces the tension of fibroblastic reticular cells. Enlargement of LNs upon inflammation is significantly disturbed in gp38-deficient mice (79). Of note, RA FLS of the intimal lining express more gp38 than OA FLS (62), and platelets in the synovium preferentially express CLEC2 (80). However, it remains to be investigated whether gp38 is also involved in hypertrophy of the RA synovium. Treatments targeting integrins or other adhesion molecules may be candidate alternatives for patients with refractory synovial hyperplasia. 


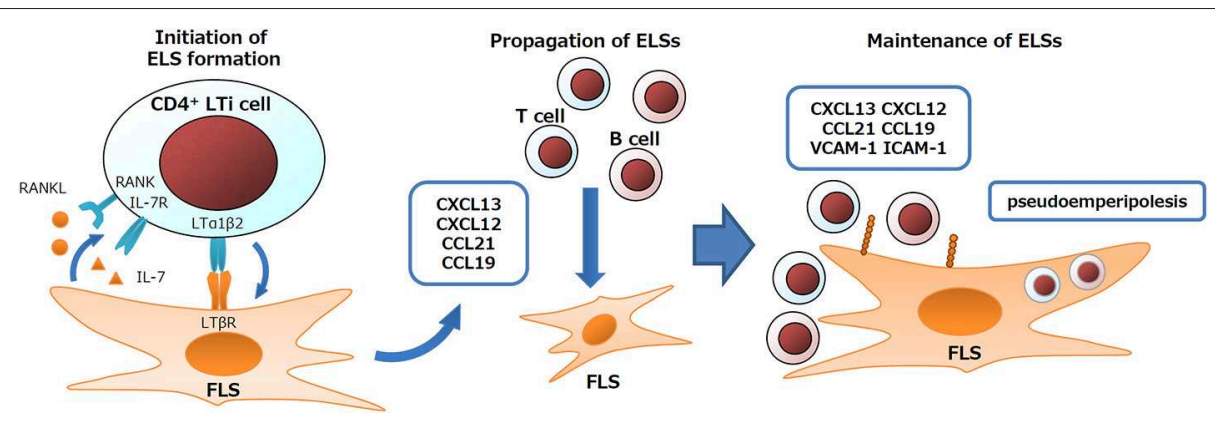

FIGURE 2 | Schematic outline of FLS contribution to TLO formation.

\section{Neoangiogenesis in the RA Synovium}

The transitory pre-vascular inflammatory stage of the RA synovium is followed by a prominent vascular stage $(46,81)$, which is clinically detectable by power Doppler (PD) sonography as a reliable sign of active synovitis, and is significantly correlated with the poor prognosis of RA (82). The clinical connection between $\mathrm{PD}$-positive synovial hyperplasia and the poor prognosis of RA strongly suggests the importance of the synovial vasculature in the RA pathogenesis. Hyperplasia of the intimal lining and infiltration of T cells, B cells, and macrophages into the sublining increase the metabolite demand and hypoxia, which induces marked new vessel formation (81). In particular, hypoxia accompanied by synovial hyperplasia drives the production of VEGF, the most important factor for neoangiogenesis, via the hypoxia-inducible transcription factor (HIF)-1 $\alpha$, whereas HIF- $2 \alpha$ is involved in FLS functions of intimal lining (83-86). Subsequently, upregulated VEGF leads to the activation of the angiopoietin (Ang)/Tie-2 system. Although Ang1 is constitutively expressed by quiescent vasculature, the expression of Ang2 depends on endothelial cell activation (87). The activation of Tie-2 signaling via the Akt pathway is required for the proliferation and survival of endothelial cells (81). Observation of Tie-2 activation in synovial tissues from some unestablished RA patients might imply the involvement of angiogenesis process in the development of RA (88). Of note, RA FLS under hypoxic conditions are sufficient for angiogenesis employing multiple factors such VEGF, bFGF, TGF- $\beta$, IL-6, IL-8, CXCL12, ICAM1 , VCAM-1, and matrix metalloproteinases $(84,89)$. In the context of the clinical relevance of PD for the development of joint destruction, treatments targeting HIF- $1 \alpha$ or angiogenic factors have been discussed as alternative treatments for RA $(81,90)$.

\section{Direct Effector Functions of FLS}

One important feature of RA is the direct contribution of FLS to the degeneration of joints. Models of FLS transplanted together with cartilage into immunodeficient mice demonstrated that once activated, RA FLS acquire an aggressive phenotype that invades adjacent cartilage (91). RA FLS secrete multiple species of extracellular protease enzymes such as matrix metalloproteinases (MMPs). MMPs can be subdivided according to their substrates into collagenases, stromelysins, gelatinases, and membrane-type MMPs. The collagenases MMP-1 and MMP-13, and the stromelysin MMP-3 are the most important MMPs in the RA pathogenesis (3). FLS also produce tissue inhibitors of metalloproteinases (TIMPs). Cartilage destruction depends on the balance between MMPs and TIMPs. When the balance favors MMPs, cartilage degradation proceeds. The expression of MMPs, but not TIMPS, is upregulated by inflammatory cytokines (IL-1 $\beta$, TNF, and IL-17) (3), which is consistent with the correlation between inflammation and cartilage degradation.

A disintegrin and metalloproteinase with thrombospondin motifs (ADAMTs) comprise another family of extracellular proteases. ADAMTS4 and ADAMTS5 produced by FLS lead to cartilage damage in RA (92). Adhesion molecules, such as integrins and cadherins, are also involved in cartilage degeneration. As described above, FLS in the intimal lining increase the expression of MMPs via signaling of integrin $\alpha 9$ and cadherin $11(77,78)$. RA FLS also express higher amounts of integrin $\alpha 5 \beta 1$, which plays an important role together with syndecan 4 in the adhesion of cells to, and destruction of, the cartilage matrix (93). Another essential function of FLS is osteoclastogenesis, which is also involved in joint destruction, via RANKL and M-CSF secretion. Although activated T cells also produce RANKL, conditional knockout in vivo experiments revealed that FLS contribute to bone destruction more than $\mathrm{T}$ cells (63).

\section{CONCLUSION}

Several studies on RA have confirmed that FLS-non-immune cells found in target organs-play several roles in disease development. These findings have increased our understanding of the immune responses of ELSs at local inflammatory sites. However, many questions remain to be answered about the immune responses at local inflammatory sites, including autoantibody development in ELSs and the complex roles of helper $\mathrm{T}$ cells. Recent single-cell analysis has demonstrated that FLS can be classified into several subsets (94). Further investigation of the interactions between FLS and immune cells will improve our understanding of human immunology and aid in the development of new RA treatments. 


\section{AUTHOR CONTRIBUTIONS}

The author confirms being the sole contributor of this work and has approved it for publication.

\section{REFERENCES}

1. Pitzalis C, Jones GW, Bombardieri M, Jones SA. Ectopic lymphoid-like structures in infection, cancer and autoimmunity. Nat Rev Immunol. (2014) 14:447-62. doi: 10.1038/nri3700

2. Schellekens GA, Visser H, de Jong BA, van den Hoogen FH, Hazes JM, Breedveld FC, et al. The diagnostic properties of rheumatoid arthritis antibodies recognizing a cyclic citrullinated peptide. Arthritis Rheum. (2000) 43:155-63. doi: 10.1002/1529-0131(200001)43:1>155::AID-ANR20<3. $0 . \mathrm{CO} ; 2-3$

3. Bartok B, Firestein GS. Fibroblast-like synoviocytes: key effector cells in rheumatoid arthritis. Immunol Rev. (2010) 233:233-55. doi: 10.1111/j.0105-2896.2009.00859.x

4. Ospelt C, Brentano F, Rengel Y, Stanczyk J, Kolling C, Tak PP, et al. Overexpression of toll-like receptors 3 and 4 in synovial tissue from patients with early rheumatoid arthritis: toll-like receptor expression in early and longstanding arthritis. Arthritis Rheum. (2008) 58:3684-92. doi: 10.1002 /art.24140

5. Brentano F, Schorr O, Gay RE, Gay S, Kyburz D. RNA released from necrotic synovial fluid cells activates rheumatoid arthritis synovial fibroblasts via Toll-like receptor 3. Arthritis Rheum. (2005) 52:2656-65. doi: 10.1002/art. 21273

6. Ebid R, Lichtnekert J, Anders HJ. Hyaluronan is not a ligand but a regulator of toll-like receptor signaling in mesangial cells: role of extracellular matrix in innate immunity. ISRN Nephrol. (2014) 2014:714081. doi: $10.1155 / 2014 / 714081$

7. Sanchez-Pernaute O, Filkova M, Gabucio A, Klein M, Maciejewska-Rodrigues $\mathrm{H}$, Ospelt $\mathrm{C}$, et al. Citrullination enhances the pro-inflammatory response to fibrin in rheumatoid arthritis synovial fibroblasts. Ann Rheum Dis. (2013) 72:1400-6. doi: 10.1136/annrheumdis-2012-201906

8. Sohn DH, Rhodes C, Onuma K, Zhao X, Sharpe O, Gazitt T, et al. Local Joint inflammation and histone citrullination in a murine model of the transition from preclinical autoimmunity to inflammatory arthritis. Arthritis Rheumatol. (2015) 67:2877-87. doi: 10.1002/art.39283

9. Hatterer E, Shang L, Simonet P, Herren S, Daubeuf B, Teixeira S, et al. A specific anti-citrullinated protein antibody profile identifies a group of rheumatoid arthritis patients with a toll-like receptor 4-mediated disease. Arthritis Res Ther. (2016) 18:224. doi: 10.1186/s13075-016-1128-5

10. Kyburz D, Rethage J, Seibl R, Lauener R, Gay RE, Carson DA, et al. Bacterial peptidoglycans but not $\mathrm{CpG}$ oligodeoxynucleotides activate synovial fibroblasts by toll-like receptor signaling. Arthritis Rheum. (2003) 48:642-50. doi: $10.1002 /$ art. 10848

11. Carmona-Rivera C, Carlucci PM, Moore E, Lingampalli N, Uchtenhagen H, James E, et al. Synovial fibroblast-neutrophil interactions promote pathogenic adaptive immunity in rheumatoid arthritis. Sci Immunol. (2017) 2:eaag3358. doi: 10.1126/sciimmunol.aag3358

12. Bombardieri M, Lewis M, Pitzalis C. Ectopic lymphoid neogenesis in rheumatic autoimmune diseases. Nat Rev Rheumatol. (2017) 13:141-54. doi: 10.1038/nrrheum.2016.217

13. Doorenspleet ME, Klarenbeek PL, de Hair MJ, van Schaik BD, Esveldt RE, van Kampen $\mathrm{AH}$, et al. Rheumatoid arthritis synovial tissue harbours dominant B-cell and plasma-cell clones associated with autoreactivity. Ann Rheum Dis. (2014) 73:756-62. doi: 10.1136/annrheumdis-2012-202861

14. Kiener HP, Watts GF, Cui Y, Wright J, Thornhill TS, Skold M, et al. Synovial fibroblasts self-direct multicellular lining architecture and synthetic function in three-dimensional organ culture. Arthritis Rheum. (2010) 62:742-52. doi: 10.1002/art.27285

15. Alvaro-Gracia JM, Zvaifler NJ, Firestein GS. Cytokines in chronic inflammatory arthritis. IV. Granulocyte/macrophage colony-stimulating factor-mediated induction of class II MHC antigen on human monocytes:

\section{FUNDING}

This review is supported by JSPS KAKENHI Grant Number JP19H03780.

a possible role in rheumatoid arthritis. J Exp Med. (1989) 170:865-75. doi: 10.1084/jem.170.3.865

16. Maini RN, Breedveld FC, Kalden JR, Smolen JS, Davis D, Macfarlane JD, et al. Therapeutic efficacy of multiple intravenous infusions of anti-tumor necrosis factor alpha monoclonal antibody combined with low-dose weekly methotrexate in rheumatoid arthritis. Arthritis Rheum. (1998) 41:1552-63. doi: 10.1002/1529-0131(199809)41:9\&lt;1552::AID-ART5\&gt;3.0.CO;2-W

17. Choy EH, Isenberg DA, Garrood T, Farrow S, Ioannou Y, Bird H, et al. Therapeutic benefit of blocking interleukin- 6 activity with an anti-interleukin6 receptor monoclonal antibody in rheumatoid arthritis: a randomized, double-blind, placebo-controlled, dose-escalation trial. Arthritis Rheum. (2002) 46:3143-50. doi: 10.1002/art.10623

18. Firestein GS. Evolving concepts of rheumatoid arthritis. Nature. (2003) 423:356-61. doi: 10.1038/nature01661

19. Yellin M, Paliienko I, Balanescu A, Ter-Vartanian S, Tseluyko V, Xu LA, et al. A phase II, randomized, double-blind, placebo-controlled study evaluating the efficacy and safety of MDX-1100, a fully human anti-CXCL10 monoclonal antibody, in combination with methotrexate in patients with rheumatoid arthritis. Arthritis Rheum. (2012) 64:1730-9. doi: 10.1002/art.34330

20. Burmester GR, McInnes IB, Kremer J, Miranda P, Korkosz M, Vencovsky $\mathrm{J}$, et al. A randomised phase IIb study of mavrilimumab, a novel GM-CSF receptor alpha monoclonal antibody, in the treatment of rheumatoid arthritis. Ann Rheum Dis. (2017) 76:1020-30. doi: 10.1136/annrheumdis-2016-210624

21. Fuller K, Wong B, Fox S, Choi Y, Chambers TJ. TRANCE is necessary and sufficient for osteoblast-mediated activation of bone resorption in osteoclasts. J Exp Med. (1998) 188:997-1001. doi: 10.1084/jem.188.5.997

22. Yasuda H, Shima N, Nakagawa N, Yamaguchi $K$, Kinosaki M, Mochizuki S, et al. Osteoclast differentiation factor is a ligand for osteoprotegerin/osteoclastogenesis-inhibitory factor and is identical to TRANCE/RANKL. Proc Natl Acad Sci USA. (1998) 95:3597-602. doi: 10.1073/pnas.95.7.3597

23. Lacey DL, Timms E, Tan HL, Kelley MJ, Dunstan CR, Burgess T, et al. Osteoprotegerin ligand is a cytokine that regulates osteoclast differentiation and activation. Cell. (1998) 93:165-76. doi: 10.1016/S0092-8674(00)81569-X

24. Cohen SB, Dore RK, Lane NE, Ory PA, Peterfy CG, Sharp JT, et al. Denosumab treatment effects on structural damage, bone mineral density, and bone turnover in rheumatoid arthritis: a twelve-month, multicenter, randomized, double-blind, placebo-controlled, phase II clinical trial. Arthritis Rheum. (2008) 58:1299-309. doi: 10.1002/art.23417

25. Wellcome Trust Case Control Consortium. Genome-wide association study of 14,000 cases of seven common diseases and 3,000 shared controls. Nature. (2007) 447:661-78. doi: 10.1038/nature05911

26. Weinblatt ME, Schiff M, Valente R, van der Heijde D, Citera G, Zhao C, et al. Head-to-head comparison of subcutaneous abatacept versus adalimumab for rheumatoid arthritis: findings of a phase IIIb, multinational, prospective, randomized study. Arthritis Rheum. (2013) 65:28-38. doi: 10.1002/art.37711

27. Hirota K, Hashimoto M, Yoshitomi H, Tanaka S, Nomura T, Yamaguchi $\mathrm{T}$, et al. $\mathrm{T}$ cell self-reactivity forms a cytokine milieu for spontaneous development of IL-17(+) Th cells that cause autoimmune arthritis. J Exp Med. (2007) 204:41-7. doi: 10.1084/jem.20062259

28. King C, Tangye SG, Mackay CR. T follicular helper (TFH) cells in normal and dysregulated immune responses. Annu Rev Immunol. (2008) 26:741-66. doi: 10.1146/annurev.immunol.26.021607.090344

29. Rao DA. T cells that help B cells in chronically inflamed tissues. Front Immunol. (2018) 9:1924. doi: 10.3389/fimmu.2018.01924

30. Benedetti G, Miossec P. Interleukin 17 contributes to the chronicity of inflammatory diseases such as rheumatoid arthritis. Eur J Immunol. (2014) 44:339-47. doi: 10.1002/eji.201344184

31. Genovese MC, Durez P, Richards HB, Supronik J, Dokoupilova E, Mazurov V, et al. Efficacy and safety of secukinumab in patients with rheumatoid arthritis: 
a phase II, dose-finding, double-blind, randomised, placebo controlled study. Ann Rheum Dis. (2013) 72:863-9. doi: 10.1136/annrheumdis-2012-201601

32. Papp KA, Langley RG, Sigurgeirsson B, Abe M, Baker DR, Konno P, et al. Efficacy and safety of secukinumab in the treatment of moderate-to-severe plaque psoriasis: a randomized, double-blind, placebo-controlled phase II dose-ranging study. Br J Dermatol. (2013) 168:412-21. doi: 10.1111/bjd.12110

33. Crotty S. Follicular helper CD4 T cells (T-FH). Annu Rev Immunol. (2011) 29:621-63. doi: 10.1146/annurev-immunol-031210-101400

34. Manzo A, Vitolo B, Humby F, Caporali R, Jarrossay D, Dell'Accio F, et al. Mature antigen-experienced $\mathrm{T}$ helper cells synthesize and secrete the B cell chemoattractant CXCL13 in the Inflammatory environment of the rheumatoid joint. Arthritis Rheum. (2008) 58:3377-87. doi: 10.1002/art. 23966

35. Kobayashi S, Murata K, Shibuya H, Morita M, Ishikawa M, Furu M, et al. A distinct human CD4+T cell subset that secretes CXCL13 in rheumatoid synovium. Arthritis Rheum. (2013) 65:3063-72. doi: 10.1002/art.38173

36. Rao DA, Gurish MF, Marshall JL, Slowikowski K, Fonseka CY, Liu Y, et al. Pathologically expanded peripheral $\mathrm{T}$ helper cell subset drives $\mathrm{B}$ cells in rheumatoid arthritis. Nature. (2017) 542:110-4. doi: 10.1038/nature20810

37. Yoshitomi H, Kobayashi S, Miyagawa-Hayashino A, Okahata A, Doi K, Nishitani K, et al. Human Sox4 facilitates the development of CXCL13producing helper T cells in inflammatory environments. Nat Commun. (2018) 9:3762. doi: 10.1038/s41467-018-06187-0

38. Kobayashi S, Watanabe T, Suzuki R, Furu M, Ito H, Ito J, et al. TGF-beta induces the differentiation of human CXCL13-producing CD4(+) T cells. Eur J Immunol. (2016) 46:360-71. doi: 10.1002/eji.201546043

39. Zheng SG, Wang JH, Stohl W, Kim KS, Gray JD, Horwitz DA. TGF-beta requires CTLA- 4 early after $\mathrm{T}$ cell activation to induce FoxP3 and generate adaptive CD4+CD25+ regulatory cells. J Immunol. (2006) 176:3321-9. doi: 10.4049/jimmunol.176.6.3321

40. Manel N, Unutmaz D, Littman DR. The differentiation of human $T(H)-17$ cells requires transforming growth factor-beta and induction of the nuclear receptor RORgammat. Nat Immunol. (2008) 9:641-9. doi: 10.1038/ni.1610

41. Proost P, Verpoest S, Van de Borne K, Schutyser E, Struyf S, Put W, et al. Synergistic induction of CXCL9 and CXCL11 by toll-like receptor ligands and interferon-gamma in fibroblasts correlates with elevated levels of CXCR3 ligands in septic arthritis synovial fluids. J Leukoc Biol. (2004) 75:777-84. doi: 10.1189/jlb.1003524

42. Ueno A, Yamamura M, Iwahashi M, Okamoto A, Aita T, Ogawa N, et al. The production of CXCR3-agonistic chemokines by synovial fibroblasts from patients with rheumatoid arthritis. Rheumatol Int. (2005) 25:361-7. doi: 10.1007/s00296-004-0449-x

43. Tanida S, Yoshitomi H, Nishitani K, Ishikawa M, Kitaori T, Ito H, et al. CCL20 produced in the cytokine network of rheumatoid arthritis recruits CCR6(+) mononuclear cells and enhances the production of IL-6. Cytokine. (2009) 47:112-8. doi: 10.1016/j.cyto.2009.05.009

44. Nanki T, Imai T, Nagasaka K, Urasaki Y, Nonomura $Y$, Taniguchi K, et al. Migration of CX3CR1-positive $\mathrm{T}$ cells producing type 1 cytokines and cytotoxic molecules into the synovium of patients with rheumatoid arthritis. Arthritis Rheum. (2002) 46:2878-83. doi: 10.1002/art.10622

45. Tanaka Y, Takeuchi T, Umehara H, Nanki T, Yasuda N, Tago F, et al. Safety, pharmacokinetics, and efficacy of E6011, an antifractalkine monoclonal antibody, in a first-in-patient phase 1/2 study on rheumatoid arthritis. Mod Rheumatol. (2018) 28:58-65. doi: 10.1080/14397595.2017.1337056

46. Neumann E, Lefevre S, Zimmermann B, Gay S, Muller-Ladner U. Rheumatoid arthritis progression mediated by activated synovial fibroblasts. Trends $\mathrm{Mol}$ Med. (2010) 16:458-68. doi: 10.1016/j.molmed.2010.07.004

47. Moingeon P, Chang HC, Wallner BP, Stebbins C, Frey AZ, Reinherz EL. CD2mediated adhesion facilitates $\mathrm{T}$ lymphocyte antigen recognition function. Nature. (1989) 339:312-4. doi: 10.1038/339312a0

48. Mori M, Hashimoto M, Matsuo T, Fujii T, Furu $M$, Ito $H$, et al. Cell-contact-dependent activation of $\mathrm{CD} 4(+) \mathrm{T}$ cells by adhesion molecules on synovial fibroblasts. Mod Rheumatol. (2017) 27:448-56. doi: 10.1080/14397595.2016.1220353

49. Edwards JC, Szczepanski L, Szechinski J, Filipowicz-Sosnowska A, Emery P, Close DR, et al. Efficacy of B-cell-targeted therapy with rituximab in patients with rheumatoid arthritis. $N$ Engl J Med. (2004) 350:2572-81. doi: 10.1056/NEJMoa032534
50. Bombardieri M, Kam NW, Brentano F, Choi K, Filer A, Kyburz D, et al. A BAFF/APRIL-dependent TLR3-stimulated pathway enhances the capacity of rheumatoid synovial fibroblasts to induce AID expression and Ig class-switching in B cells. Ann Rheum Dis. (2011) 70:1857-65. doi: 10.1136/ard.2011.150219

51. Vincent FB, Morand EF, Schneider P, Mackay F. The BAFF/APRIL system in SLE pathogenesis. Nat Rev Rheumatol. (2014) 10:365-73. doi: $10.1038 /$ nrrheum.2014.33

52. Chevalier N, Jarrossay D, Ho E, Avery DT, Ma CS, Yu D, et al. CXCR5 expressing human central memory $\mathrm{CD} 4 \mathrm{~T}$ cells and their relevance for humoral immune responses. J Immunol. (2011) 186:5556-68. doi: 10.4049/jimmunol.1002828

53. Stohl W, Merrill JT, McKay JD, Lisse JR, Zhong ZJ, Freimuth WW, et al. Efficacy and safety of belimumab in patients with rheumatoid arthritis: a phase II, randomized, double-blind, placebo-controlled, dose-ranging Study. J Rheumatol. (2013) 40:579-89. doi: 10.3899/jrheum.120886

54. Hunter CA, Jones SA. IL-6 as a keystone cytokine in health and disease. Nat Immunol. (2015) 16:448-57. doi: 10.1038/ni.3153

55. Dienz O, Eaton SM, Bond JP, Neveu W, Moquin D, Noubade R, et al. The induction of antibody production by IL-6 is indirectly mediated by IL-21 produced by CD4+ T cells. J Exp Med. (2009) 206:69-78. doi: 10.1084/jem.20081571

56. Gu-Trantien C, Loi S, Garaud S, Equeter C, Libin M, de Wind A, et al. CD4(+) follicular helper $\mathrm{T}$ cell infiltration predicts breast cancer survival. J Clin Invest. (2013) 123:2873-92. doi: 10.1172/JCI67428

57. Moyron-Quiroz JE, Rangel-Moreno J, Hartson L, Kusser K, Tighe MP, Klonowski KD, et al. Persistence and responsiveness of immunologic memory in the absence of secondary lymphoid organs. Immunity. (2006) 25:643-54. doi: 10.1016/j.immuni.2006.08.022

58. Canete JD, Celis R, Moll C, Izquierdo E, Marsal S, Sanmarti R, et al. Clinical significance of synovial lymphoid neogenesis and its reversal after antitumour necrosis factor alpha therapy in rheumatoid arthritis. Ann Rheum Dis. (2009) 68:751-6. doi: 10.1136/ard.2008.089284

59. Braun A, Takemura S, Vallejo AN, Goronzy JJ, Weyand CM. Lymphotoxin beta-mediated stimulation of synoviocytes in rheumatoid arthritis. Arthritis Rheum. (2004) 50:2140-50. doi: 10.1002/art.20356

60. Bradfield PF, Amft N, Vernon-Wilson E, Exley AE, Parsonage G, Rainger GE, et al. Rheumatoid fibroblast-like synoviocytes overexpress the chemokine stromal cell-derived factor 1 (CXCL12), which supports distinct patterns and rates of $\mathrm{CD} 4+$ and $\mathrm{CD} 8+\mathrm{T}$ cell migration within synovial tissue. Arthritis Rheum. (2003) 48:2472-82. doi: 10.1002/art.11219

61. Pickens SR, Chamberlain ND, Volin MV, Pope RM, Mandelin AMII, Shahrara S. Characterization of CCL19 and CCL21 in rheumatoid arthritis. Arthritis Rheum. (2011) 63:914-22. doi: 10.1002/art.30232

62. Ekwall AK, Eisler T, Anderberg C, Jin C, Karlsson N, Brisslert M, et al. The tumour-associated glycoprotein podoplanin is expressed in fibroblast-like synoviocytes of the hyperplastic synovial lining layer in rheumatoid arthritis. Arthritis Res Ther. (2011) 13:R40. doi: 10.1186/ar3274

63. Danks L, Komatsu N, Guerrini MM, Sawa S, Armaka M, Kollias G, et al. RANKL expressed on synovial fibroblasts is primarily responsible for bone erosions during joint inflammation. Ann Rheum Dis. (2016) 75:1187-95. doi: 10.1136/annrheumdis-2014-207137

64. Harada S, Yamamura M, Okamoto H, Morita Y, Kawashima M, Aita T, et al Production of interleukin-7 and interleukin- 15 by fibroblast-like synoviocytes from patients with rheumatoid arthritis. Arthritis Rheum. (1999) 42:1508-16. doi: 10.1002/1529-0131(199907)42:7\&lt;1508::AID-ANR26\&gt;3.0.CO;2-L

65. Dechanet J, Merville P, Durand I, Banchereau J, Miossec P. The ability of synoviocytes to support terminal differentiation of activated B cells may explain plasma cell accumulation in rheumatoid synovium. J Clin Invest. (1995) 95:456-63. doi: 10.1172/JCI117685

66. Chan A, Filer A, Parsonage G, Kollnberger S, Gundle R, Buckley CD, et al. Mediation of the proinflammatory cytokine response in rheumatoid arthritis and spondylarthritis by interactions between fibroblast-like synoviocytes and natural killer cells. Arthritis Rheum. (2008) 58:707-17. doi: 10.1002/art.23264

67. Bekiaris V, Sedy JR, Rossetti M, Spreafico R, Sharma S, Rhode-Kurnow A, et al. Human CD4+CD3- innate-like T cells provide a source of TNF and lymphotoxin-alphabeta and are elevated in rheumatoid arthritis. J Immunol. (2013) 191:4611-8. doi: 10.4049/jimmunol.1301672 
68. Corsiero E, Bombardieri M, Carlotti E, Pratesi F, Robinson W, Migliorini $\mathrm{P}$, et al. Single cell cloning and recombinant monoclonal antibodies generation from RA synovial $B$ cells reveal frequent targeting of citrullinated histones of NETs. Ann Rheum Dis. (2016) 75:1866-75. doi: 10.1136/annrheumdis-2015-208356

69. Corsiero E, Pratesi F, Prediletto E, Bombardieri M, Migliorini P. NETosis as source of autoantigens in rheumatoid arthritis. Front Immunol. (2016) 7:485. doi: 10.3389/fimmu.2016.00485

70. Corsiero E, Jagemann L, Perretti M, Pitzalis C, Bombardieri M. Characterization of a synovial B cell-derived recombinant monoclonal antibody targeting stromal calreticulin in the rheumatoid joints. J Immunol. (2018) 201:1373-81. doi: 10.4049/jimmunol.1800346

71. Rims C, Uchtenhagen H, Kaplan MJ, Carmona-Rivera C, Carlucci P, Mikecz K, et al. Citrullinated aggrecan epitopes as targets of auto-reactive CD4+ T cells in patients with rheumatoid arthritis. Arthritis Rheumatol. (2018) 71:518-28. doi: 10.1002/art.40768

72. Wilkinson KA, Henley JM. Mechanisms, regulation and consequences of protein SUMOylation. Biochem J. (2010) 428:133-45. doi: 10.1042/BJ20100158

73. Ahn JK, Oh JM, Lee J, Bae EK, Ahn KS, Cha HS, et al. Increased extracellular survivin in the synovial fluid of rheumatoid arthritis patients: fibroblast-like synoviocytes as a potential source of extracellular survivin. Inflammation. (2010) 33:381-8. doi: 10.1007/s10753-010-9196-1

74. Zhang Q, Wu J, Cao Q, Xiao L, Wang L, He D, et al. A critical role of Cyr61 in interleukin-17-dependent proliferation of fibroblast-like synoviocytes in rheumatoid arthritis. Arthritis Rheum. (2009) 60:3602-12. doi: 10.1002/art.24999

75. Bartok B, Boyle DL, Liu Y, Ren P, Ball ST, Bugbee WD, et al. PI3 kinase delta is a key regulator of synoviocyte function in rheumatoid arthritis. Am J Pathol. (2012) 180:1906-16. doi: 10.1016/j.ajpath.2012.01.030

76. Shibuya H, Yoshitomi H, Murata K, Kobayashi S, Furu M, Ishikawa M, et al. TNF alpha, PDGF, and TGF beta synergistically induce synovial lining hyperplasia via inducible PI3K delta. Mod Rheumatol. (2015) 25:72-8. doi: 10.3109/14397595.2014.900847

77. Lee DM, Kiener HP, Agarwal SK, Noss EH, Watts GF, Chisaka O, et al. Cadherin-11 in synovial lining formation and pathology in arthritis. Science. (2007) 315:1006-10. doi: 10.1126/science.1137306

78. Emori T, Hirose J, Ise K, Yomoda JI, Kasahara M, Shinkuma T, et al. Constitutive activation of integrin alpha9 augments self-directed hyperplastic and proinflammatory properties of fibroblast-like synoviocytes of rheumatoid arthritis. J Immunol. (2017) 199:3427-36. doi: 10.4049/jimmunol.1700941

79. Astarita JL, Cremasco V, Fu J, Darnell MC, Peck JR, Nieves-Bonilla JM, et al. The CLEC-2-podoplanin axis controls fibroblastic reticular cell contractility and lymph node microarchitecture. Nat Immunol. (2015) 16:7584. doi: 10.1038/ni.3035

80. Del Rey MJ, Fare R, Izquierdo E, Usategui A, Rodriguez-Fernandez JL, Suarez-Fueyo A, et al. Clinicopathological correlations of podoplanin (gp38) expression in rheumatoid synovium and its potential contribution to fibroblast platelet crosstalk. PLoS ONE. (2014) 9:e99607. doi: 10.1371/journal.pone.0099607

81. Leblond A, Allanore Y, Avouac J. Targeting synovial neoangiogenesis in rheumatoid arthritis. Autoimmun Rev. (2017) 16:594-601. doi: 10.1016/j.autrev.2017.04.005

82. Naredo E, Collado P, Cruz A, Palop MJ, Cabero F, Richi P, et al. Longitudinal power Doppler ultrasonographic assessment of joint inflammatory activity in early rheumatoid arthritis: predictive value in disease activity and radiologic progression. Arthritis Rheum. (2007) 57:116-24. doi: 10.1002/art.22461
83. Muz B, Khan MN, Kiriakidis S, Paleolog EM. Hypoxia. The role of hypoxia and HIF-dependent signalling events in rheumatoid arthritis. Arthritis Res Ther. (2009) 11:201. doi: 10.1186/ar2568

84. del Rey MJ, Izquierdo E, Caja S, Usategui A, Santiago B, Galindo $\mathrm{M}$, et al. Human inflammatory synovial fibroblasts induce enhanced myeloid cell recruitment and angiogenesis through a hypoxia-inducible transcription factor 1alpha/vascular endothelial growth factor-mediated pathway in immunodeficient mice. Arthritis Rheum. (2009) 60:2926-34. doi: $10.1002 /$ art. 24844

85. Elshabrawy HA, Chen Z, Volin MV, Ravella S, Virupannavar S, Shahrara S. The pathogenic role of angiogenesis in rheumatoid arthritis. Angiogenesis. (2015) 18:433-48. doi: 10.1007/s10456-015-9477-2

86. Ryu JH, Chae CS, Kwak JS, Oh H, Shin Y, Huh YH, et al. Hypoxia-inducible factor-2alpha is an essential catabolic regulator of inflammatory rheumatoid arthritis. PLoS Biol. (2014) 12:e1001881. doi: 10.1371/journal.pbio.1001881

87. Fiedler U, Augustin HG. Angiopoietins: a link between angiogenesis and inflammation. Trends Immunol. (2006) 27:552-8. doi: 10.1016/j.it.2006. 10.004

88. van de Sande MG, de Launay D, de Hair MJ, Garcia S, van de Sande GP, Wijbrandts CA, et al. Local synovial engagement of angiogenic TIE2 is associated with the development of persistent erosive rheumatoid arthritis in patients with early arthritis. Arthritis Rheum. (2013) 65:3073-83. doi: 10.1002/art.38128

89. Del Rey MJ, Izquierdo E, Usategui A, Gonzalo E, Blanco FJ, Acquadro F, et al. The transcriptional response of normal and rheumatoid arthritis synovial fibroblasts to hypoxia. Arthritis Rheum. (2010) 62:3584-94. doi: 10.1002/art.27750

90. Westra J, Molema G, Kallenberg CG. Hypoxia-inducible factor-1 as regulator of angiogenesis in rheumatoid arthritis - therapeutic implications. Curr Med Chem. (2010) 17:254-63. doi: 10.2174/092986710790149783

91. Muller-Ladner U, Kriegsmann J, Franklin BN, Matsumoto S, Geiler T, Gay RE, et al. Synovial fibroblasts of patients with rheumatoid arthritis attach to and invade normal human cartilage when engrafted into SCID mice. Am J Pathol. (1996) 149:1607-15.

92. Rengel Y, Ospelt C, Gay S. Proteinases in the joint: clinical relevance of proteinases in joint destruction. Arthritis Res Ther. (2007) 9:221. doi: 10.1186/ar2304

93. Rinaldi N, Schwarz-Eywill M, Weis D, Leppelmann-Jansen P, Lukoschek $\mathrm{M}$, Keilholz U, et al. Increased expression of integrins on fibroblast-like synoviocytes from rheumatoid arthritis in vitro correlates with enhanced binding to extracellular matrix proteins. Ann Rheum Dis. (1997) 56:45-51. doi: 10.1136/ard.56.1.45

94. Mizoguchi F, Slowikowski K, Wei K, Marshall JL, Rao DA, Chang SK, et al. Functionally distinct disease-associated fibroblast subsets in rheumatoid arthritis. Nature Commun. (2018) 9:789. doi: 10.1038/s41467-01 $8-02892-y$

Conflict of Interest Statement: The author declares that the research was conducted in the absence of any commercial or financial relationships that could be construed as a potential conflict of interest.

Copyright (c) 2019 Yoshitomi. This is an open-access article distributed under the terms of the Creative Commons Attribution License (CC BY). The use, distribution or reproduction in other forums is permitted, provided the original author(s) and the copyright owner(s) are credited and that the original publication in this journal is cited, in accordance with accepted academic practice. No use, distribution or reproduction is permitted which does not comply with these terms. 